\title{
The Role of Ultrasound Elastography in Evaluation for Axillary Lymph Nodes of Patients with Breast Cancer
}

\author{
AHMED M. MONIB, M.D.; MARIAM K.F. MIKHAIL, M.Sc. and MOHAMED G. MANSOUR, M.D. \\ The Department of Radiology, Faculty of Medicine, Ain Shams University
}

\begin{abstract}
Background: Axillary lymph node status is the most reliable prognostic indicator for disease recurrence and patient survival in breast cancer. Axillary ultrasound is an important mean for detecting metastatic LNs, being non-invasive, available \& cheap.

Aim of Study: To investigate the role of strain elastography combined with conventional ultrasound in the diagnosis of axillary lymph nodes in patients with breast cancer.

Patients and Methods: 24 patients diagnosed with breast cancer with enlarged axillary lymph node were included in this study over the course of six months, they were examined bu B mode ultrasound and ultrasound elastography. Finally, findings of B-mode US and elastography were compared with pathological results (reference standard). ROC analysis was constructed to obtain best cutoff values for B-mode criteria, alasticity score and strain ratio.
\end{abstract}

Results: Elastography score and strain ratio had a higher specifcity ( $83.3 \%$ vs. $33.3 \%)$ and a lower sensitivity ( $88.9 \%$ vs. $100 \%$ ) than gray-scale ultrasonography. Of all the 6 benign axillary lymph nodes analysed in the present study, 2 were determined to be metastatic by gray-scale ultrasonography, while these diagnoses were corrected by RTE. As regards the semi-quantitative assessment; strain ratio, in our study there was a significant increase in mean strain ratio in the malignant nodes (1-8.3) than the benign ones (0.7-3.4) $(p=0.005)$, with the best cutoff value 2.5 which yielded sensitivity of 88.89 , specificity of 83.33 ,accuracy of $90 \%$, PPV $94.1 \%$, NPV $71.4 \%$.

Conclusion: Ultrasound elastography by its qualitative (elasticity score) and quantitative (strain ratio) evaluation has proved to useful in differentiation between benign and malignant nodes as a complementary to conventional ultrasound. Using elasticity score/strain ratio; 11 out of 18 pathologically proved malignant nodes, were diagnosed as malignant, 5 out of 6 benign nodes were diagnosed as benign.

Key Words: Lymph nodes - Ultrasound elastography - Elasticity-Breast cancer.

Correspondence to: Dr. Mariam K.F. Mikhail, E-Mail: mariam-14-5@ hotmail.com

\section{Introduction}

YEARS of cancer statistics have demonstrated that breast cancer is the most common cancer and the second leading cause of cancer-related death in women worldwide. Axillary lymph node status remains a major prognostic indicator for early breast cancer, affecting the clinical staging and patient selection for surgical procedure and adjuvant systemic therapy [1].

The status of the axillary lymph node is one of the independent factors influencing the prognosis of patients with breast cancer. The 5-year survival rate of breast cancer cases with axillary lymph node metastasis decreases by $40 \%$ compared to that of non-metastatic patients [2].

Currently, Sentinel Lymph Node Biopsy (SLNB), traditional ultrasound-guided Core Needle Biopsy (CNB), and Fine-Needle Aspiration Cytology (FNAC) are the most common procedures for identifying axillary nodal metastasis in breast cancer patients; however, these methods are invasive, requiring additional time for pathological diagnosis, and false-negative results might affect the efficacy of biopsy, due to improper selection of the target lymph node. Therefore, the use of non-invasive imaging techniques to help predict nodal status before biopsy is of great value [1]

Ultrasonography, mammography, Computed Tomography (CT), Magnetic Resonance Imaging (MRI), and Combined Positon-Emission Tomography (PET)/CT are common non-invasive preoperative methods used in the diagnosis of axillary lymph node. Oblique radiography of mammography can help to detect partial abnormal axillary lymph nodes and reveal if there is lymph node metastasis by evaluating morphology, size, and density [3] . 
But the evaluation of axillary lymph nodes using mammography is not applicable because mammography cannot cover the entire axillary. Breast MRI has excellent soft-tissue resolution; however, axillary lymph nodes cannot be included in their entirety because of the limited range of the breast coil [4].

Ultrasound, as a non-invasive technique, is often used to distinguish malignant from benign axillary lymph nodes based on morphological characteristics pre-operatively. Ultrasound is a convenient tool as it provides real-time imaging, high soft-tissue resolution, feasibility and costefficiency; however, traditional ultrasound has moderate sensitivity for identifying malignant lymph nodes and false-positive results leading to unnecessary biopsy.

With advances in medical imaging, ultrasound elastography has received considerable attention in the last years for its non invasive ability to assess tissue stiffness in various organs [5].

Real-Time (strain) Elastography (RTE) and Shear-Wave Elastography (SWE) are the two most widely used elastographic techniques. RTE demonstrates a colour map imposed on the 2D image, which is obtained through applying constant stress to the tissue. It can be used qualitatively (elasticity score) or semi-quantitatively (strain ratio) to access the stiffness of lesions [6].

Our study will use real time elastography.

\section{Aim of the work:}

To investigate the role of strain elastography combined with conventional ultrasound in the diagnosis of axillary lymph nodes in patients with breast cancer.

\section{Patients and Methods}

The study was a prospective study, it included 24 patients in this study enrolled at Ain Shams University Hospitals over the course of six months between March 2020 and August 2020. An informed consent explaining the procedure details was obtained from all patients prior to inclusion in this study. The study was conducted according to the stipulations of the ASU ethical and scientific committee. The privacy of participants and confidentiality of data were guaranteed during the various phases of the study. The inclusion criteria were: Patients with breast cancer, only females. The exclusion criteria were: (A) History of neoad- juvant therapy; (B) Ductal carcinoma in situ; (C) The suspected axillary lymph node located adjacent to the main axillary vessels so that it would be risky to perform a biopsy.

Study tools and procedures: After consent achievement and fully explained about the steps of research, all 24 known patients were subjected to the following: Complete history taking and thorough clinical examination. B-mode ultrasound, and UE were examined to determine LN characteristics. Scores of elastographic classification and a Strain Ratio (SR) were used to evaluate the ultrasound elastograms. The patient's pathology report obtained from the patient.

\section{Technique:}

All 24 patients known patient with breast cancer and suspected axillary lymph nodes involvement underwent axillary ultrasound examination by $\mathrm{B}$ mode, sonoelastography and finally histopathological examination. Machine: GE healthcare Logic P9 ultrasound with a $6-15 \mathrm{MHz}$ superficial linear transducer.

\section{Conventional breast ultrasound:}

To examine the axilla the patient was scanned in the supine oblique position with the ipsi-lateral hand behind her head so that the arm is abducted and externally rotated. Axillary US is performed with the same high-frequency linear array transducer that is used for breast imaging. Nodes should be imaged in the orthogonal planes with gray-scale US.

Image analysis and interpretation of conventional ultrasound:

Each examined axillary lymph node was evaluated regarding: Short and long axis diameters. Shape (ovoid or non-ovoid). Cortical thickening (present or not, and if present "diffuse or focal"). Fatty hilum (central, effaced, eccentric or notpreserved) and each examined lymph node was categorized as (benign, indeterminate, and malignant) blinded to the final pathology.

\section{Elastogram evaluation:}

Compression with light pressure followed by decompression was repeated until a stable image was obtained and the pressure index scaled up and stably lasted 2 or 3 seconds. Direction of the compression is upward and downward. Real-time elastographic and B-mode images simultaneously appear together as a two-panel image, the elastogram appear in the Region of Interest (ROI) box. The size of the box is adjusted according to the 
size of the target lymph node. The color scale ranged from red (ie, softest component) to blue (ie, hardest component), we assess color distribution in cortex and medulla of lymph nodes. Afterward, elastographic images were given elasticity scores of 1 to 5 which based on the percentage of the stiff areas as follows: 1 , the green portion occupied almost all of the cortex; 2 , the blue portion occupied less than $50 \%$ of the cortex; 3 , the blue portion occupied more than $50 \%$ of the cortex, with scattered the green portions; 4 , the blue portion occupied almost all of the cortex; 5, the blue portion occupied almost all of the cortex, with a green ring on the edge of the node. To measure the strain ratio a circular ROI was placed in the axillary fat and a second ROI of the same size and same level was placed over the stiffest part of the examined lymph node (this allow calculation of Strain Ratio (SR).

Histopathologic diagnosis by following and receiving the pathology report from the patient.

\section{Statistical analysis:}

Recorded data were analyzed using the statistical package for social sciences, version 20.0 (SPSS Inc., Chicago, Illinois, USA). Quantitative data were expressed as mean \pm Standard Deviation (SD). Qualitative data were expressed as frequency and percentage.

The following tests were done: Chi-square $\left(\chi^{2}\right)$ test of significance was used in order to compare proportions between qualitative parameters. The confidence interval was set to $95 \%$ and the margin of error accepted was set to $5 \%$. So, the $p$-value was considered significant as the following: Probability ( $p$-value). $p$-value $\leq 0.05$ was considered significant. $p$-value $\leq 0.001$ was considered as highly significant. $p$-value $>0.05$ was considered insignificant.

\section{Results}

The mean age of women was $52.54 \pm 10.58$. The pathological results of 24 axillary lymph nodes were reported, and $18(75 \%)$ were determined to be metastatic, while the other $6(25 \%)$ nodes were determined to be benign. The most common histological type in the examined patients was invasive duct carcinoma $66.7 \%$.

\section{B-mode ultrasound criteria:}

The mean \pm standard deviation of transverse diameter, short axis, long axis/short diameter (L/S) diameter, cortical thickness, focal thickening, shape and state hilum in the examined lymph nodes were calculated (Table 1).
Table (1): The mean \pm standard deviation of transverse diameter, short axis, long axis/short diameter (L/S) diameter, cortical thickness, focal thickening, shape and state hilum in the examined lymph nodes.

\begin{tabular}{ll}
\hline B mode & Total no. $=24$ \\
\hline Transverse diameter: & \\
$\quad$ Mean \pm SD & $2.18 \pm 0.67$ \\
$\quad$ Range & $0.9-3.3$ \\
Short axis: & \\
$\quad$ Mean \pm SD & $1.13 \pm 0.42$ \\
$\quad$ Range & $0.5-2.1$ \\
L/S diameter: & \\
$\quad$ Mean \pm SD & $1.91 \pm 0.82$ \\
$\quad$ Range & $0-3.6$ \\
Cortical thickness: & \\
$\quad$ Median (IQR) & $0.8(0.5-1.3)$ \\
$\quad$ Range & $0.3-3$ \\
Focal thickening: & \\
$\quad$ No & $10(41.7 \%)$ \\
$\quad$ Yes & $14(58.3 \%)$ \\
Shape: & \\
$\quad$ Ovoid & $12(50.0 \%)$ \\
Rounded & $12(50.0 \%)$ \\
Hilum: & \\
Preserved & $5(20.8 \%)$ \\
Compressed & $13(54.2 \%)$ \\
Absent & $6(25.0 \%)$ \\
\hline
\end{tabular}

Table (2): The significance values of B mode ultrasound criteria.

\begin{tabular}{llllll}
\hline & $\begin{array}{c}\text { Benign } \\
\text { No.=6 }\end{array}$ & $\begin{array}{c}\text { Malignant } \\
\text { No.=18 }\end{array}$ & $\begin{array}{c}\text { Test } \\
\text { value }\end{array}$ & $\begin{array}{c}p \text { - } \\
\text { value }\end{array}$ & Sig. \\
\hline $\begin{array}{l}\text { Longitudinal: } \\
\text { - Mean } \pm \text { SD }\end{array}$ & $\begin{array}{l}2.22 \pm 0.60 \\
\text { - Range }\end{array}$ & $\begin{array}{l}2.17 \pm 0.71 \\
\text { - }\end{array}$ & $0.137 \bullet$ & 0.893 & NS \\
Short axis: & & & & & \\
- Mean \pm SD & $0.88 \pm 0.3 .3$ & $1.22 \pm 0.45$ & $-1.735 \bullet$ & 0.097 & NS \\
- Range & $0.6-1.3$ & $0.5-2.1$ & & & \\
L/S diameter: & & & & & \\
- Mean \pm SD & $2.84 \pm 0.90$ & $1.86 \pm 0.67$ & $2.834 \bullet$ & 0.010 & $S$ \\
- Range & $1.78-4.13$ & $0.95-3.5$ & & & \\
Cortical & & & & & \\
thickness: & & & & & \\
- Median (IQR) & 0.45 & 0.95 & $-1.980 \neq$ & 0.048 & $\mathrm{~S}$ \\
& $(0.4-0.7)$ & $(0.5-1.37)$ & & & \\
- Range & $0.3-1.5$ & $0.4-3$ & & & \\
- Absent & $0(0.0 \%)$ & $6(33.3 \%)$ & & & \\
\hline
\end{tabular}

The mean long axis diameter of malignant nodes was not significantly higher than benign nodes ( $p=0.893$ ), the mean short axis of malignant nodes was not significantly higher than benign nodes $(p=0.097)$ and the mean $\mathrm{L} / \mathrm{S}$ of malignant nodes was significantly lower than benign nodes $(p=0.010)$ also cortical thickness of malignant lymph nodes was significantly higher than benign lymph nodes $(p=0.048)$ (Table 2$)$. 
Table (3): The focal thickening, shape and state of hilum in benign and malignant lymph nodes.

\begin{tabular}{|c|c|c|c|c|c|}
\hline & $\begin{array}{l}\text { Benign } \\
\text { No.=6 }\end{array}$ & $\begin{array}{c}\text { Malignant } \\
\text { No. }=18\end{array}$ & $\begin{array}{c}\text { Test } \\
\text { value }\end{array}$ & $\begin{array}{c}p- \\
\text { value }\end{array}$ & Sig. \\
\hline \multicolumn{6}{|l|}{$\begin{array}{l}\text { Focal } \\
\text { thickening: }\end{array}$} \\
\hline $\begin{array}{l}\text { - No } \\
\text { - Yes }\end{array}$ & $\begin{array}{l}2(33.3 \%) \\
4(66.7 \%)\end{array}$ & $\begin{array}{ll}8 & (44.4 \%) \\
10 & (55.6 \%)\end{array}$ & $0.229 *$ & 0.633 & NS \\
\hline \multicolumn{6}{|l|}{ Shape: } \\
\hline $\begin{array}{l}\text { - Ovoid } \\
\text { - Rounded }\end{array}$ & $\begin{array}{l}5(83.3 \%) \\
1(16.7 \%)\end{array}$ & $\begin{array}{ll}7 & (38.9 \%) \\
11 & (61.1 \%)\end{array}$ & $3.556^{*}$ & 0.059 & NS \\
\hline \multicolumn{6}{|l|}{ Hilum: } \\
\hline - Preserved & $4(66.7 \%)$ & $1 \quad(5.6 \%)$ & $10.708^{*}$ & 0.005 & HS \\
\hline $\begin{array}{l}\text { - Compressed } \\
\text { - Absent }\end{array}$ & $\begin{array}{l}2(33.3 \%) \\
0(0.0 \%)\end{array}$ & $11(61.1 \%)$ & & & \\
\hline
\end{tabular}

The state of hilum in malignant lymph nodes shows significant difference than in benign lymph nodes ( $p=0.005$ ) while there's no significant difference between benign and malignant lymph nodes regarding the shape $(p=0.059)$ or the presence of focal thickening $(p=0.633)$ (Table 3$)$.

Table (4): Cutoffs of significant B mode criteria and their diagnostic performance (ROC curve analysis).

Variables $\begin{gathered}\text { Cut off } \\ \text { point }\end{gathered}$ AUC Sensitivity Specificity +PV -PV $\begin{array}{lllllll}\text { - } \mathrm{L} / \mathrm{S} & \leq 2.08 & 0.852 & 77.78 & 83.33 & 93.3 & 55.6\end{array}$

diameter

$\begin{array}{llllll}\text { - Cortical >0.7 } & 0.773 & 66.67 & 83.33 & 92.3 & 45.5\end{array}$ thickness

Table (5): Diagnostic criteria of B mode criteria.

\begin{tabular}{|c|c|c|c|c|c|c|c|c|c|}
\hline & $\mathrm{TP}$ & $\mathrm{TN}$ & FP & FN & Sensitivity & Specificity & PPV & NPV & Accuracy \\
\hline $\mathrm{L} / \mathrm{S}$ diameter $(\leq 2.08)$ & 14 & 5 & 1 & 4 & 77.8 & 83.3 & 93.3 & 55.6 & 0.792 \\
\hline Cortical thickness (>7) & 12 & 5 & 1 & 6 & 66.7 & 83.3 & 92.3 & 45.5 & 0.708 \\
\hline Focal thickening & 10 & 2 & 4 & 8 & 55.6 & 33.3 & 71.4 & 20.0 & 0.500 \\
\hline Shape (rounded) & 11 & 5 & 1 & 7 & 61.1 & 83.3 & 91.7 & 41.7 & 0.667 \\
\hline Absent or compressed Hilum & 17 & 4 & 2 & 1 & 94.4 & 66.7 & 89.5 & 80.0 & 0.875 \\
\hline Total B mood & 18 & 2 & 4 & 0 & $100.0 \%$ & $33.3 \%$ & $81.8 \%$ & $100.0 \%$ & 0.833 \\
\hline $\begin{array}{l}p \text {-value }>0.05 \text { : Non significant. } \\
p \text {-value }<0.05 \text { : Significant. } \\
p \text {-value }<0.01 \text { : Highly significant. }\end{array}$ & & & & & $\begin{array}{l}*: \text { Chi-square } \\
\because: \text { Independen } \\
\neq: \text { Mann-Whi }\end{array}$ & $\begin{array}{l}\text { test. } \\
\text { it } t \text {-test. } \\
\text { tney test. }\end{array}$ & & & \\
\hline
\end{tabular}

Table (6): Diagnostic performance of the B mode summation score (ROC curve analysis).

\begin{tabular}{|c|c|c|c|c|c|c|c|c|c|}
\hline & $\mathbf{T P}$ & $\Gamma N$ & FP & $\mathrm{N}$ & Sensitivity & Specificity & PPV & NPV & Accuracy \\
\hline Total B mood & 18 & 2 & 4 & 0 & $100.0 \%$ & $33.3 \%$ & $81.8 \%$ & $100.0 \%$ & 0.833 \\
\hline
\end{tabular}

Table (7): Distribution of elasticity score in benign and malignant lymph nodes. (Chi-squared test).

\begin{tabular}{|c|c|c|c|c|c|}
\hline \multirow{2}{*}{ ES } & \multicolumn{2}{|c|}{ Benign $\Longrightarrow$} & \multirow{2}{*}{ value } & \multirow{2}{*}{$\begin{array}{l}\text { Dalue } \\
\text { valu }\end{array}$} & \multirow{2}{*}{ Sig. } \\
\hline & No.=6 & No. $=18$ & & & \\
\hline 1 & $1(16.7 \%)$ & $0(0.0 \%)$ & $12.444^{*}$ & 0.014 & S \\
\hline 2 & $3(50.0 \%)$ & $1(5.6 \%)$ & & & \\
\hline 3 & $1(16.7 \%)$ & $1(5.6 \%)$ & & & \\
\hline 4 & $1(16.7 \%)$ & $11(61.1 \%)$ & & & \\
\hline 5 & $0(0.0 \%)$ & $5(27.8 \%)$ & & & \\
\hline Mean \pm SD & $2.33 \pm 1.03$ & $4.11 \pm 0.76$ & $-4.550^{*}$ & 0.000 & HS \\
\hline Range & $1-4$ & $2-5$ & & & \\
\hline
\end{tabular}

Table (8): Cutoff value of elasticity score and its diagnostic performance. (ROC curve analysis).

\begin{tabular}{lccccc}
\hline Variables & $\begin{array}{c}\text { Cut off } \\
\text { point }\end{array}$ & AUC & Sensitivity Specificity & + PV & -PV \\
\hline ES & $>3$ & 0.903 & 88.89 & 83.33 & 94.171 .4 \\
\hline
\end{tabular}

Table (9): Median value, of strain ratio in benign and malignant nodes. ( $t$-test)

\begin{tabular}{lllccc}
\hline $\begin{array}{l}\text { Strain } \\
\text { ratio }\end{array}$ & $\begin{array}{c}\text { Benign } \\
\text { No.=6 }\end{array}$ & $\begin{array}{c}\text { Malignant } \\
\text { No.=18 }\end{array}$ & $\begin{array}{c}\text { Test } \\
\text { value }\end{array}$ & $\begin{array}{c}p \text { - } \\
\text { value }\end{array}$ & Sig. \\
\hline Median & $\begin{array}{l}1.15(1-2.5) \\
\leq 2.5\end{array}$ & $\begin{array}{l}3.5(2.9-5) \\
(100.0 \%)\end{array}$ & $\begin{array}{l}2(11.1 \%) \\
16.000 *\end{array}$ & 0.000 & HS \\
$>2.5$ & $0(0.0 \%)$ & $16(88.9 \%)$ & & & \\
\hline
\end{tabular}

The mean value of malignant nodes was significantly higher than benign nodes ( $p$-value $<0.0001)$.

The mean value of strain ratio is significantly higher in malignant nodes than benign ( $p$-value $<0.0001)$.

Table (10): Best strain ratio cutoff value and its diagnostic performance (ROC curve analysis).

\begin{tabular}{|c|c|c|c|c|c|}
\hline & $\begin{array}{c}\text { Cut off } \\
\text { point }\end{array}$ & AUC & Sensitivity & Specificity & $+\mathrm{PV}-\mathrm{PV}$ \\
\hline $\begin{array}{l}\text { Strain } \\
\text { ratio }\end{array}$ & $>2.5$ & 0.889 & 88.89 & 83.33 & 94.171 .4 \\
\hline
\end{tabular}




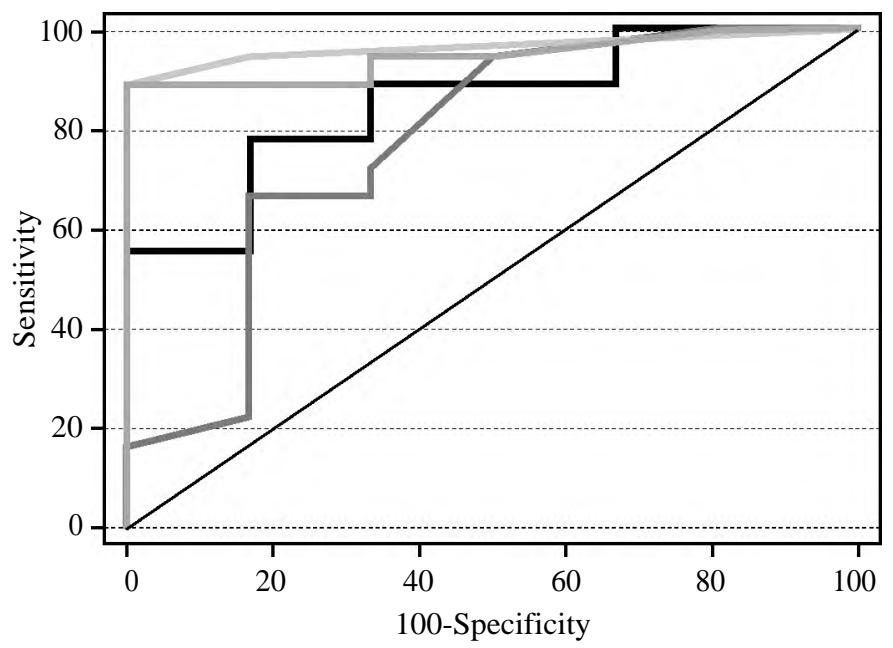

\section{L/S diameter $\quad$ ES \\ Cortical thickness $\quad$ Strain ratio}

Fig. (1): Receiver operating characteristic (ROC) curve for L/S diameter, cortical thickness, ES and strain ratio.
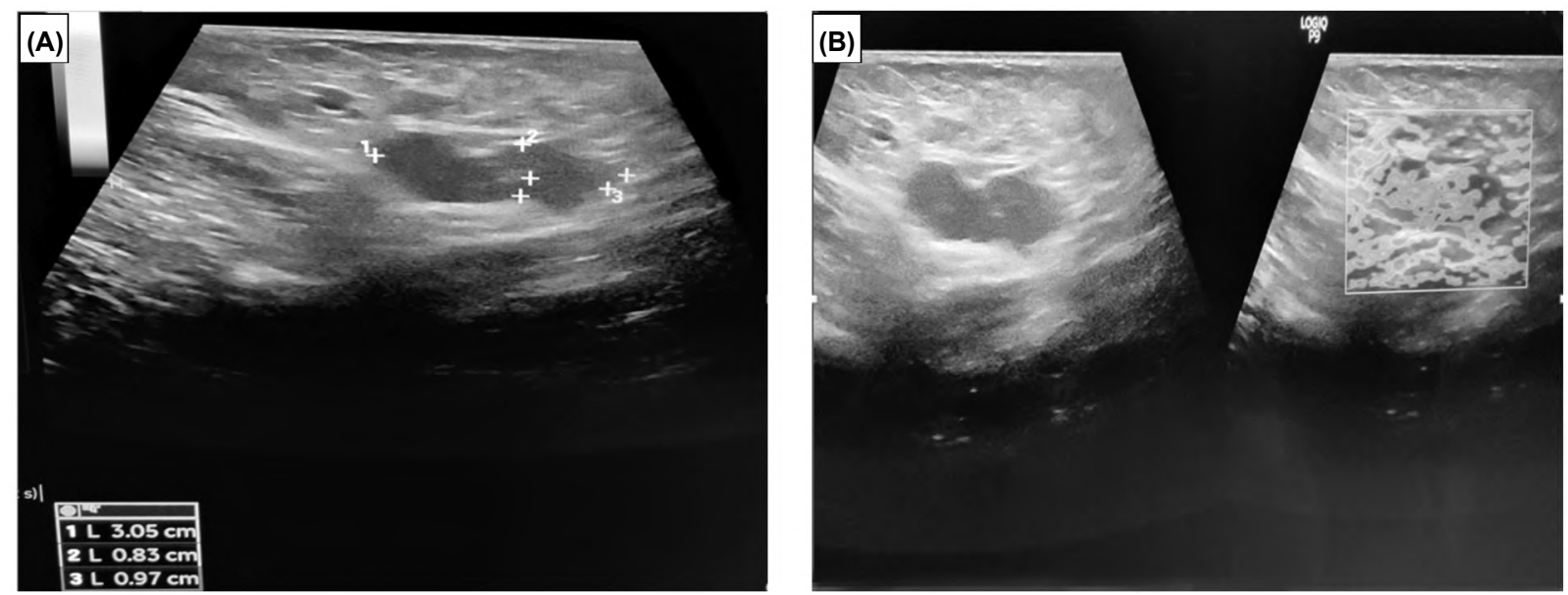

Fig. (2): (A) Enlarged sized hypoechoic axillary LN which is oval in shape, with increased focal cortical thickening \& large, with eccentric hilum, "Considered as Indeterminate LN" by B mode. (B) Strain Elastography examination revealed the hard areas of the cortex (blue in color) representing <50\% of the cortex (score 2) "considered as benign". The measured strain ratio $(\mathrm{SR})=1$, "Considered as benign". Pathological examination revealed reactive lymph node.
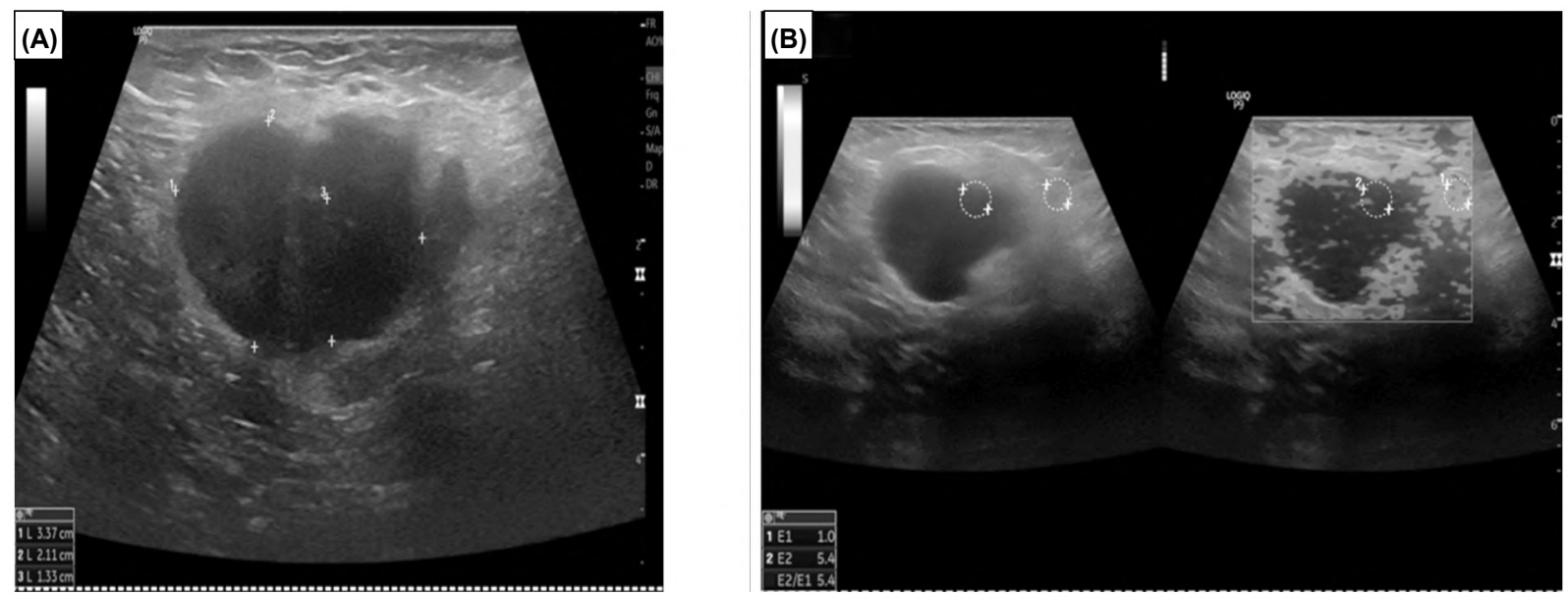

Fig. (3): (A) Axillary lymph node hypoechoic rather rounded in shape, with focal cortical thickening \& faint eccentric hilum. "Considered as malignant LN" by B mode. (B) By ultrasound elastography the hard areas of the cortex (blue in color) representing most of the cortex (score 4)" Considered as malignant". The measured strain ratio (SR)=5.4, "Considered as Malignant", pathological examination revealed metatstatic lymph node. 

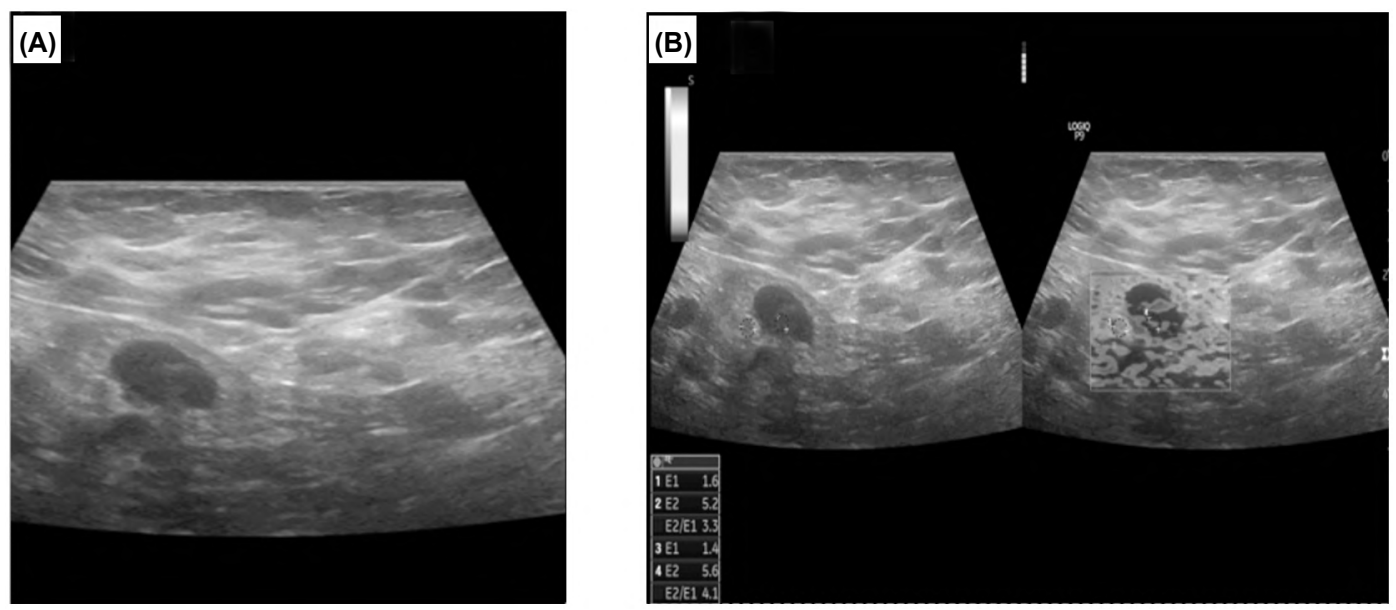

Fig. (4): (A) Axillary lymph node round in shape, with rather diffuse cortical thickening \& faint compressed fatty hilum, "considered as intermediate LN" by B mode. (B) Ultrasound elastography showed thard areas of the cortex (blue in color) representing most of the cortex with surrounding green rim (score 5) considered as malignant ". The measured strain ratio $(\mathrm{SR})=4$, "considered as malignant" pathology examination revealed to be metastatic lymph node.

\section{Discussion}

Lymphatic metastasis is an important prognostic factor in patients with cancer. Determination of nodal status is also critical for appropriate treatment planning. Although lymph nodes can be detected and visualized by several imaging modalities including Ultrasound (US), Computed Tomography (CT) and Magnetic Resonance Imaging (MRI), the differentiation between benign and malignant lymph nodes remains challenging [7].

Enlarged reactive nodes are frequently present along the lymphatic drainage pathways, particularly of large and necrotic tumors, which may mimic lymph node metastasis [8]

Ultrasound (US) is the noninvasive diagnostic tool most commonly used in the assessment of the axilla. The dimensional (transverse diameter greater than a threshold value, ratio between longitudinal and transverse diameters, cortical thickness) and morphological criteria (abnormal shape, altered hilum, regional nodal grouping, extra capsular tumor spread, or presence of necrosis) on which the US diagnosis of nodal metastases is based, however, are not completely reliable [9].

In this study we used Ultrasound Elastography to differentiate between benign and malignant enlarged axillary lymph nodes with pathologic correlation of results. This study included 24 female patients diagnosed with breast cancer, their age ranged from 35 to 75 years.

Choi et al., [10] classified the B mode ultrasound findings of 64 axillary lymph nodes into 4 criteria:
Transverse diameter, longitudinal to transverse diameter ratio, presence of the hilum, and shape of the cortex, they found that the mean transverse diameter of metastatic axillary lymph nodes (11.3 $\pm 6.4 \mathrm{~mm}$ ) was significantly larger than the diameter of reactive axillary lymph nodes $(5.1 \pm 1.6 \mathrm{~mm}$; $p<0.001)$ in contrast to our study which found that the mean transverse diameter of lymph nodes wasn't significant in differentiation between benign and metastatic lymph nodes $(p=0.097)$. Also no difference was found in the mean longitudinal to transverse axis diameter ratios between reactive and metastatic lymph nodes $(p=0.286)$ as opposed to our study where the mean longitudinal to transverse axis diameter ratios was significantly lower in malignant lymph nodes than benign lymph nodes $(p=0.010)$.

Absence of the hilum and eccentric cortical thickening were associated with metastatic lymph nodes ( $p=0.004$ and 0.012 , respectively) in agreement to our study.

In our study of 24 axillary lymph nodes by B mode US, we evaluated 5 criteria; longitudinal axis diameter, short axis, L/S diameter ratio, cortical thickness and the state of hilum. We found that; the mean longitudinal axis of malignant nodes $(2.17 \pm 0.71 \mathrm{~cm})$ was not significantly higher than that of benign nodes $(2.22 \pm 0.60)$ ( $p$-value $=0.893)$. the mean transverse axis of malignant lymph nodes $(1.22 \pm 0.45 \mathrm{~cm})$ (was also not significantly higher than that of benign nodes $(0.88 \pm 0.23 \mathrm{~cm})(p$-value $=$ $0.097)$. The mean longitudinal to transverse diameter $(\mathrm{L} / \mathrm{T})$ ratio in malignant nodes $(1.86 \pm 0.67 \mathrm{~cm})$ was significantly higher than its mean value in 
benign nodes $(2.84 \pm 0.90)(p$-value $=0.010)$. The median cortical thickness in malignant nodes 0.95 $(0.5-1.3 \mathrm{~cm})$ was significantly higher than that of benign nodes $0.45(0.4-0.7 \mathrm{~cm}) 0(p$-value $=0.048)$ compressed and faint hila were significantly associated with malignant nodes $(p=0.005)$, round shape was not significantly associated with malignant nodes $(p=0.059)$.

Regarding the whole conventional ultrasound findings in our study, 2/24 (8.3\%) LNs diagnosed by US as benign. While collectively $22 / 24(91.7 \%)$ LNs diagnosed by US as malignant, (12/24 (50\%) of LNs were actually categorized as indeterminate LNs), and out of which 9/12 (25\%) LNs proved to be benign by pathology.

These results match with a study done by Chang et al., [11], who analyzed 140 visible axillary lymph nodes on conventional US imaging and all of them underwent elastography. They found that the metastatic nodes had a thicker cortex as compared to non-metastatic axillary lymph nodes. Also Abe et al., [12] reported that cortical thickening was the most sensitive for the detection of axillary lymph node metastases.

In our study the most sensitive B mode criteria was the state of hilum, the pathologically proven malignant LNs (18/24 LNs) showed mostly (effaced or eccentric) hila versus the benign LNs (6/24 LNs) which showed mainly central hila. This criterion sensitivity (94.4\%) agrees with study done by Abe et al., [12]. Their study was conducted on 50 patients with 60 enlarged axillary lymph nodes (20 male and 30 female), underwent Grey scale, color-power Doppler US and strain elastography, and found that lost or compressed nodal hilum were the most sensitive ultrasound feature predictive of malignancy that was found in $42(93.33 \%)$ out of 45 malignant lymph nodes and false positive in one lymph node.

Also, in our study LNs that showed eccentric or lost fatty hila were mostly proved to be malignant by pathology $(94.4 \%)$, this result compared with the results found by Youk et al., [13], stated that $(82 \%)$ of the LNs showed eccentric or lost hila are confirmed to be malignant.

In our study, there was no significant difference between benign and metastatic lymph nodes in shape unlike the study by Youk et al., [13], significantly larger proportions of metastatic axillary lymph nodes had a round shape $(80 \%$ vs. $63 \%$, $p=0.033$ ).
Regarding the qualitative scoring of strain elastography in our study we used the same score as $\mathrm{Xu}$ et al., [6] where elastography scores were reported on a scale of 1 to 5 . Te pattern of the elastograms of the lymph nodes were divided into two groups: Those with or those without hila. In our study, according to the ROC curve analysis, the cutoff value for malignancy was $>3$ for elastography ultrasound. The nodes that were scored 1 or 2 or 3 were considered benign, and those that were scored 4 or 5 were considered metastatic based on elastography. The sensitivity, specificity, PPV, NPV and accuracy were 88.89, 83.33, 94.1, $71.478 \%$, respectively while $\mathrm{Xu}$ et al., cut off was 3 and it showed higher sensitivity and specificity $(93 \%, 93 \%)$ respectively.

Choi et al., [10] has proposed a 4-point scoring system where score 1 stands for absent or very small blue area, score 2 indicates small, scattered blue areas, with total blue area $<45 \%$, score 3 indicates large blue area, with total blue area $\geq 45 \%$ and score 4 stands for blue area all over the node area with or without a surrounding green rim". Cutoff value for malignancy was best at score $>2$, which yielded resulted of $88.9 \%$ sensitivity, $73.3 \%$ specificity, $86.7 \%$ accuracy, $88.9 \% \mathrm{PPV}$ and $83.3 \%$ NPV.

Furukawa et al., [14] also used a similar four pattern score in 45 patients where score $1 ;>80 \%$ of the node area is soft (red or green), score 2; 50$80 \%$ of the node area is soft (green or red), score $3 ; 50-80 \%$ of the area is blue and score $4 ;>80 \%$ of the node area is blue. They found that scores 3 and 4 are only observed in malignant nodes. 32 of 34 malignant nodes $(94.1 \%)$ showed score 3 and 4 , whereas score 1 and 2 are encountered in all 11 benign nodes and 2 of 34 malignant nodes (5.9\%). Score $>2$ as cutoff for malignancy yielded results of $74.4 \%$ sensitivity and $97.1 \%$ specificity.

Zhang et al., [15] used score in a study of 112 subjects with 155 lymph nodes with B-mode sonography and elastography to evaluate the value of elastography in the differential diagnosis of the benign and malignant superficial lymph nodes. They found that most of the elastographic findings of the benign lymph nodes; 66 of 68 (97.1\%), were rated as scores 1 and 2 and most of the malignant ones; 72 of $87(71.3 \%)$, were rated as scores 3 and 4. Two benign lymph nodes and 10 malignant ones were indeterminate. Using score $>2$ as cutoff for malignancy, yielded sensitivity of $74.7 \%$, specificity of $97.1 \%$ and accuracy of $84.5 \%$. 
As regards the semi-quantitative assessment; strain ratio, in our study there was a significant increase in mean strain ratio in the malignant nodes $(1-8.3)$ than the benign ones $(0.7-3.4)(p=0.005)$, with the best cutoff value 2.5 which yielded sensitivity of 88.89 , specificity of 83.33 , accuracy of 90\%, PPV $94.1 \%$, NPV $71.4 \%$.

Choi et al., [10] as well stated that the strain ratio for metastatic axillary lymph nodes $(7.1 \pm 9.0)$ was significantly higher than the ratio for reactive axillary lymph nodes $(3.5 \pm 3.9) ;(p=.007)$. With the best strain ratio cutoff of 2.3, the sensitivity, specificity, PPV, NPV, and accuracy were $82.8 \%$, $56.3 \% 61.5 \%, 77.3 \%$, and $67.2 \%$, respectively.

In agreement with our study, Zhang et al., [15] found that the strain ratio of the malignant lymph nodes was higher than that of the benign ones with the best strain ratio cutoff point was 2.395 , with the sensitivity and specificity of $78.41 \%$ and 98.51\%, AUC was 0.915.

In the study done by Xu et al., [6], the strain ratio ranged from 0.49 to 46.55 . The strain ratio for metastatic axillary lymph nodes $(12.64 \pm 5.30)$ was significantly higher than that for reactive axillary lymph nodes $(2.35 \pm 1.80)$. With the best strain ratio cutoff of 2.62 , the sensitivity, specificity, PPV, NPV, and accuracy were $87 \%, 76 \%, 80 \%$, $83 \%$ and $81 \%$, respectively.

The difference in the results between our study and the other studies probably was related to the different type of device used, Choi and co-workers utilized EUB-850 scanner (Hitachi Medical Corporation, Tokyo, Japan), while in our study we used (GE LOGIQ P9). Also tissue compression can influence elastographic images. Extensive experience may be needed to obtain reproducible results [10].

Elastography score and strain ratio had a higher specifcity $(83.3 \%$ vs. $33.3 \%)$ and a lower sensitivity $(88.9 \%$ vs. $100 \%)$ than gray-scale ultrasonography. Of all the 6 benign axillary lymph nodes analysed in the present study, 2 were determined to be metastatic by gray-scale ultrasonography, while these diagnoses were corrected by RTE.

\section{Conclusion:}

Ultrasound elastography by its qualitative (elasticity score) and quantitative (strain ratio) evaluation has proved to useful in differentiation between benign and malignant nodes as a complementary to conventional ultrasound. Using elasticity score/ strain ratio; 11 out of 18 pathologically proved malignant nodes, were diagnosed as malignant, 5 out of 6 benign nodes were diagnosed as benign.

\section{References}

1- TANG G.X., XIAO X.Y., XU X.L., YANG H.Y., CAI Y.C., LIU X.D., TIAN J. and LUO B.M.: Diagnostic value of ultrasound elastography for differentiation of benign and malignant axillary lymph nodes: A meta-analysis. Clin. Radiol., Jun., 75 (6): 481.e9-481.e16, 2020.

2- RIIS M.: Modern surgical treatment of breast cancer. Ann. Med. Surg. (Lond). Jun. 23; 56: 95-107, 2020.

3- WU P.Q., LIU C.L., LIU Z.Y., YE W.T. and LIANG C.H.: [Value of mamography, CT and DCE-MRI in detecting axillary lymph node metastasis of breast cancer]. Nan. Fang Yi Ke Da Xue Xue Bao, 36 (4): 493-9, 2016.

4- JAVID S., SEGARA D., LOTFI P., RAZA S. and GOLSHAN M.: Can breast MRI predict axillary lymph node metastasis in women undergoing neoadjuvant chemotherapy. Ann. Surg. Oncol., 17 (7): 1841-6, 2010.

5- SIGRIST R.M.S., LIAU J., KAFFAS A.E., CHAMMAS M.C. and WILLMANN J.K.: Ultrasound Elastography: Review of Techniques and Clinical Applications. Theranostics, 7 (5): 1303-29, 2017.

6- XU Y., BAI X., CHEN Y., JIANG L., HU B., HU B. and YU L.: Application of Real-time Elastography Ultrasound in the Diagnosis of Axillary Lymph Node Metastasis in Breast Cancer Patients. Sci. Rep., 8 (1): 10234, 2018.

7- ZHANG G.C., ZHANG Y.F., XU F.P., QIAN X.K., GUO Z.B., REN C.Y. and YAO M.: Axillary lymph node status, adjusted for pathologic complete response in breast and axilla after neoadjuvant chemotherapy, predicts differential disease-free survival in breast cancer. Curr. Oncol., 20 (3): e180-92, 2013.

8- LEI J., XUE H.D., LI Z., LI S. and JIN Z.Y.: Possible pathological basis for false diagnoses of lymph nodes by USPIO-enhanced MRI in rabbits. J. Magn. Reson. Imaging, 31 (6): 1428-34, 2010.

9- FORNASA F., NESOTI M.V., BOVO C. and BONAVINA M.G.: Diffusion-weighted magnetic resonance imaging in the characterization of axillary lymph nodes in patients with breast cancer. J. Magn. Reson. Imaging, 36 (4): 85864, 2012.

10- CHOI J.J., KANG B.J., KIM S.H., LEE J.H., JEONG S.H., YIM H.W., SONG B.J. and JUNG S.S.: Role of sonographic elastography in the differential diagnosis of axillary lymph nodes in breast cancer. J. Ultrasound Med., 30 (4): 429-36, 2011

11- CHANG J.M., WON J.K., LEE K.B., PARK I.A., YI A. and MOON W.K.: Comparison of shear-wave and strain ultrasound elastography in the differentiation of benign and malignant breast lesions. AJR Am. J. Roentgenol., 201 (2): W347-W356, 2013.

12- ABE H., SCHACHT D., SENNETT C.A., NEWSTEAD G.M. and SCHMIDT R.A.: Utility of pre-operative ultrasound for predicting $\mathrm{pN} 2$ or higher stage axillary lymph node involvement in patients with newly diagnosed breast cancer. AJR Am. J. Roentgenol., 200 (3): 696-702, 2013. 
13- YOUK J.H., GWEON H.M. and SON E.J.: Shear-wave elastography in breast ultrasonography: The state of the art. Ultrasonography, 36 (4): 300-9, 2017.

14-FURUKAWA M.K., KUBOTA A., HANAMURA H. and FURUKAWA M.: [Clinical application of real-time tissue elastography to head and neck cancer--evaluation of cervical lymph node metastasis with real-time tissue elastography]. Nihon Jibiinkoka Gakkai Kaiho, 110 (7): 503-5, 2007.

15-ZHANG Y., LV Q., YIN Y., et al.: The value of ultrasound elastography in differential diagnosis of superficial lymph nodes. Front. Med. China, 3: 368-74, 2009.

\section{دور قياس مرونة الآنسجة بإستخدام الموجات فوق الصوتية لتقييم العقد الليمفاوية الإبطية البونية اللمرضى بسرطان الثدى المقاوي}

تعتبر حالة العقدة الليمفاوية الإبطية آكثرالعوامل موثقية فى سرطان الثىى لتكرار المرض وبقاء المريض. الموجات فوق الصوتية الإبطية هى وسيلة مهمة للكثف عن آفات العقد الليمفاوية الخبيثة، كونها غير جراحية ومتوفرة ورخيصة.

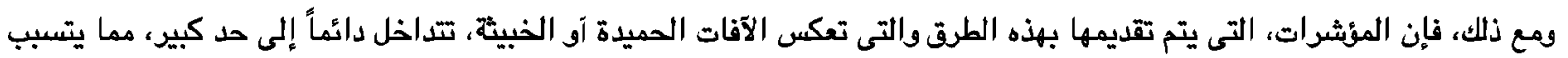

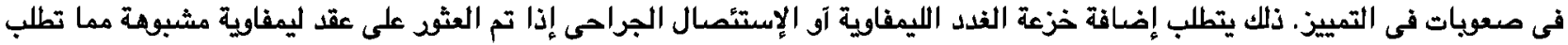
الحاجة إلى تقنية غير جراحية للتمييز الدقيق بين العقد الليمفاوية الحميدة والخبيثة.

تعد الموجات فوق الصوتية لقياس المرونة Ultrasound elastography طريقة واعدة للتمييز بين العقد الليمفاوية الإبطية الصميدة والخبيثة عن طريق قياس مرونة الآنسجة التى لا تنعكس على الموجات فوق الصوتية التقليدية. وهو يستخلم المفهوم الإكلينيكي الراستخ بآن الآفات الخبيثة

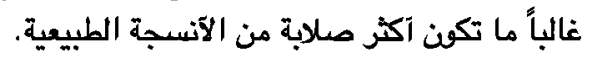

هدفت دراستنا إلى تصقيق تمايز آفضل بين الغدد الليمفاوية الإبطية الحميدة والضبيثة عن طريق الموجات فوق الصوتية لقياس المرونة

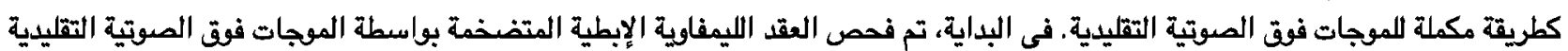
لتوصيف المعايير المشبوهة مثل الشكل والحجم وبمك القشرة ووجود نقير دهنى، ولكن وحدها، لم تكن دقيقة بما يكفى للتمييز.

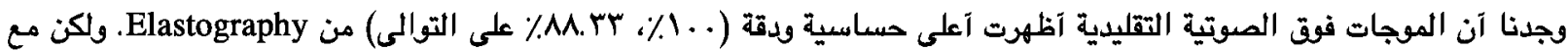
خصوصية آقل نسبياً (T.r.\%).

ثبت آن التصويز المرن بالموجات فوق الصوتية من خلال تقيمه النوعى (درجة المرونة) والكمى (نسبة الإجهاد) مفيد في التمايز بين العقد المميدة والخبيثة كمكل الموجات فوق الصوتية التقليدية.

بإستخدام درجة المرونة/نسبة الإجهاد، ال من آصل \/ عقدة خبيثة ثبت آنها خبيثة، تم تشخيص ه من 7 عقد حميدة على آنها حميدة. 